\title{
Patterns of Acid Base Balance and Plasma Electrolyte Concentrations in Post Surgical Digestive Patients
}

\author{
T. Murad El Fuad, Efori Gea, Chairul Yoel, Munar Lubis \\ (Department of Child Health, Medical School University of North Sumatera / \\ Dr. Pirngadi Hospital, Medan)
}

\begin{abstract}
Patterns of acid-base balance and plasma electrolyte concentrations of postsurgical digestive patients were studied retrospectively. The patients were treated at the Pediatric ICU Dr. Pingadi Hospital, Medan, during the period of February 1991 through January 31 1992. There were 131 patients admitted to the Pediatric ICU, 67 (51.1\%) of them had had gastrointestinal surgery. Arterial blood gas and / or plasma electrolyte examinations were done in $92 \%$ of patients within 12 hours of admission. In 50 patients both blood gas and electrolyte concentration values were examined; 6 of them died. One out of 14 patients who had only serum electrolyte concentration values died. One out of 3 patients who had neither blood gas nor plasma electrolyte concentration values died. Acid-base imbalances were found in $66 \%$ of those 50 patients, consisting of $28 \%$ metabolic acidosis, $12 \%$ respiratory alkalosis, $8 \%$ respiratory acidosis, and $6 \%$ metabolic alkalosis. Hyponatremia was found in $68.4 \%$ of the survivors and in 2 out of 6 patients who died. No hypernatremia was found in any of the patients. Hypokalemia was found in $24.6 \%$ of patients survived; and none in those who died. Hyperkalemia was encountered in $24.6 \%$ of those who survived. The overall mortality of patients who had undergone gastrointestinal surgery in the Pediatric ICU, Pirngadi Hospital, was $8 / 67$ (11.9\%). [Paediatr Indones 1993; 33: 173-81].
\end{abstract}

\section{Introduction}

The management of postsurgical patients has improved in the last decade as a result of several factors such as the development of intensive care units, advances in homeostatic monitoring system, and the application of mandatory ventilation. ${ }^{1}$ Many of those patients develop physiological alterations, either because of the preexisting disease, or as the complica- tion of surgical procedures, or both. Arterial blood gas analysis and serum electrolyte examinations may reveal the specific physiological alterations, i.e. metabolic disorder due to defective metabolism, or respiratory disorder due to respiratory or circulatory problems. ${ }^{2,3}$ However, it should be kept in mind that the diagnosis could not be made only on the basis of 
Table 1. Distribution of cases by age and sex

\begin{tabular}{ccccccc}
\hline & \multicolumn{3}{c}{ Recovered } & \multicolumn{3}{c}{ Expired } \\
\cline { 2 - 7 } $\begin{array}{c}\text { Age } \\
\text { Years }\end{array}$ & Boy & Girl & Total & Boy & Girl & Total \\
\hline-1 & 25 & 7 & 32 & 3 & 2 & 5 \\
-2 & 3 & - & 3 & - & - & - \\
-3 & - & - & - & - & - & - \\
-4 & 3 & - & 3 & - & - & - \\
-5 & 1 & - & 1 & 1 & - & 1 \\
$>5$ & 14 & 6 & 20 & 2 & - & 2 \\
\hline Total & 46 & 13 & 59 & 6 & 2 & 8 \\
\hline
\end{tabular}

Table 2. Acid base balance in 50 post surgical digestive cases

\begin{tabular}{lcc}
\hline & Recovered & Expired \\
\hline No. of cases & 44 & 6 \\
Normal balance & 15 & - \\
Acid base imbalance & - & - \\
Metabolic acidosis & 12 & - \\
Respiratory acidosis & 4 & 1 \\
Metabolic alkalosis & 3 & \\
Respiratory alkalosis & 12 & 2 \\
\hline
\end{tabular}

Table 3. Distribution of $\mathrm{pH}$ value in both groups

\begin{tabular}{ccc}
\hline $\mathrm{pH}$ & Recovered & Expired \\
\hline$<7.20$ & 2 & 2 \\
$7.20-$ & 8 & 2 \\
$7.30-$ & 13 & - \\
$7.40-$ & 14 & 2 \\
27.50 & 7 & - \\
\hline
\end{tabular}

Table 4. Distribution of $\mathrm{pCO}_{2}$ value in both groups

\begin{tabular}{lcc}
\hline $\mathrm{PCO}_{2}(\mathrm{mmHg})$ & Recovered & Expired \\
\hline$<15$ & 5 & - \\
$15-$ & 5 & 1 \\
$25-$ & 20 & 1 \\
$35-$ & 7 & 2 \\
$45-$ & 6 & 1 \\
$\geq 55$ & 1 & 1 \\
\hline
\end{tabular}

Table 5. Distribution of base excess value in both groups

\begin{tabular}{lcc}
\hline $\begin{array}{l}\text { Base excess } \\
\text { (meq/L) }\end{array}$ & Recovered & Expired \\
\hline$\leq 20$ & 9 & 2 \\
$-20-$ & 26 & 3 \\
$-10-$ & 2 & - \\
$0-$ & 7 & 1 \\
$10-$ & - & - \\
$\geq 20$ & - & - \\
\hline
\end{tabular}


Table 6. Distribution of serum $\mathrm{Na}^{+}$concentration in both groups

\begin{tabular}{lcc}
\hline $\mathrm{Na}^{+}(\mathrm{meq} / \mathrm{L})$ & Recovered & Expired \\
\hline$<110$ & - & 1 \\
$110-$ & 9 & 1 \\
$120-$ & 30 & 4 \\
$130-$ & 17 & - \\
$140-$ & 1 & 1 \\
$150-$ & - & - \\
$\geq 160$ & - & - \\
\hline
\end{tabular}

Table 7. Distribution of serum $\mathrm{K}^{+}$concentration in both groups

\begin{tabular}{lcc}
\hline $\mathrm{K}^{+}(\mathrm{meq} / \mathrm{L})$ & Recovered & Expired \\
\hline$<3.5$ & - & 1 \\
$3.5-4.5$ & 9 & 1 \\
$\geq 4.5$ & 30 & 4 \\
\hline
\end{tabular}

$5.0 \mathrm{mEq} / \mathrm{L}$ was noted among in $14 / 57$ survivors, and in $4 / 7$ of cases who died.

In this study 7 out of 8 cases who died had hyponatremia and 4 out of 6 whom the $\mathrm{pH}$ value was available showed low $\mathrm{pH}$ values. Only ' 1 case developed hypokalemia. The average duration of hospitalization was 42.75 hours.
Table 8. Distribution of expired cases by age, sex, acid base and electrolyte status and duration of hospitalization

\begin{tabular}{lllrrrrrr}
\hline No. & Age & Sex & $\mathrm{pH}$ & $\begin{array}{c}\mathrm{PCO}_{2} \\
(\mathrm{mmHg})\end{array}$ & $\begin{array}{c}\text { Base } \\
\text { excess }\end{array}$ & $\begin{array}{c}\mathrm{Na}^{+} \\
(\mathrm{meq} / \mathrm{L})\end{array}$ & $\mathrm{K}^{+}$(meq/L) & $\begin{array}{c}\text { Length of } \\
\text { hospitalization } \\
\text { (hours) }\end{array}$ \\
\hline 1 & 3 days Girl & 7.08 & 49.4 & -16.4 & 126 & 4.61 & 42 \\
2 & 5 days Girl & - & - & - & 109 & 5.36 & 4 \\
3 & 8 days Boy & 7.24 & 41.1 & -9 & 104 & 3.95 & 44 \\
4 & 5.5 mos Boy & 7.25 & 40.1 & -9.7 & 121 & 5.24 & 56 \\
5 & 7 mos Boy & - & - & - & - & - & 4 \\
6 & 5 yrs & Boy & 7.42 & 28.5 & -5.2 & 129 & $3.91-$ & 98 \\
7 & 7 yrs & Boy & 6.92 & 89.8 & -14.9 & 128 & 3.72 & 3 \\
8 & 11 yrs Boy & 7.41 & 38.4 & 0.8 & 142 & 2.02 & 91 \\
\hline
\end{tabular}

\section{Discussion}

The management of fluid, electrolytes, and acid base imbalances is important and is related and influencing each other. When the body is in disequilibrium, it basically takes two actions; $\mathrm{H}$ makes internal adjusment to either the losses or excessive and regulates it. Its products of excretion (expired air and urine) increase or decrease either the fluid, electrolyte and acids or bases. They are evidence of the return of the body to its normal acid base balance and fluid and electrolyte composition., ${ }^{1,2}$

The volume and characteristic of gastrointestinal losses may be partly assessed on the basis of the history and observation of diarrhea, stool and vomiting. The electrolyte composition of vomited fluid depends on the level of obstruction. Pure gastric juice vomited by an infant with hypertrophic pyloric stenosis usually contains $120-140 \mathrm{mEq} \mathrm{Cl} / \mathrm{L}, 10-12 \mathrm{mEq}$ $\mathrm{K}+$, and $60-75 \mathrm{mEq} \mathrm{Na}{ }^{+}$. On the other hand, bile and pancreatic juice contain $120-140 \mathrm{mEq}$ sodium, up to $100 \mathrm{mEq} \mathrm{Cl}$, and approximately $10-12 \mathrm{mEq} \mathrm{K} / \mathrm{L}$. In distal obstruction given lactated Ringer solution, one may find losses of 3.5 - 4.5 $\mathrm{g}$ protein $/ 100 \mathrm{ml}$ of peritoneal fluid leading to acid base imbalance and electrolyte cases with disturbances. Those disturbances needs optimum replacement and maintenance therapy before and during 
operation to prevent further post operative complication. ${ }^{8}$

Abnormalities found in the present study were metabolic acidosis and hyponatremia in recovered or expired cases and hypokalemia in recovered cases. There was not any hypernatremia at all found in either group. Hyperkalemia in those who died may be due to the influence of previous metabolic acidosis which was dominant in that group. These conditions were related with the pre or during operative condition of the patient. Acid base and electrolyte imbalance in patients with digestive surgical cases preoperatively, was frequently due to the high acid base and electrolyte content as a result of vomiting. The fasting patients prior to the digestive surgery, might lead to the evident of fluid, acid base and electrolyte imbalance. Significant losses of fluid electrolyte, and protein due to fasting patients is described in the Table 9.

The increased metabolic rate and body temperature influence acid base balance and serum electrolyte concentration. Inappropriate resuscitation during operative period may lead the patients into hypoxia and hemorrhage which release various component influencing the acid base and electrolyte balances. This problem could be prevented by maintaining baseline requirement and replacing fluid and electrolyte abnormalities before and during the surgical procedure.

Table 9. Losses of fluid, $\mathrm{Na}^{+}, \mathrm{K}^{+}$, carbohydrate, and protein in an hour of fasting

\begin{tabular}{ll}
\hline Body component & Losses per hour \\
\hline $\mathrm{H}_{2} \mathrm{O}$ & $60 \mathrm{ml}$ \\
$\mathrm{Na}^{+}$ & $1.8 \mathrm{meq} / \mathrm{L}$ \\
$\mathrm{K}^{+}$ & $2.1 \mathrm{meq} / \mathrm{L}$ \\
Protein & $6.1 \mathrm{~g}$ \\
Carbohydrate & $2.6 \mathrm{~g}$ \\
Fat & $5.6 \mathrm{~g}$ \\
\hline
\end{tabular}

\section{Conclusions}

Acid base and electrolyte imbalances were frequently encountered in patients who had undergone surgery for gastrointestinal disease. Adequate management of acid base balance, fluid yolume, and electrolyte concentration before and during operation is very important to prevent postoperative acid base and electrolyte imbalances. Further studies on early detection and management of acid base and electrolyte disturbances in patients undergoing gastrointestinal surgery are needed.

\section{References}

1. Muhardi, Tampubolon $Q E$, Suntoro. Analisa gas darah dalam penatalaksanaan pasien d Intensive Care Unit; Balai Penerbit Fakultas Kedokteran Ul; Jakarta; 1989; 235-43.

2. Burrell $L$ Zeb Jr, Burrell $O L$. Fluid electrolyte and acid base problems. In Critical care; 3rd ed; St. Louis, C.V. Mosby; 1977; 270-88.

3. Corral JH. Disturbances in acid base balance. In name editor Water, electrolyte, and acid base metabolism; Diagnosis and management. 2nd ed Philadelphia; editor JB Lippincott, 1989; 20686.

4. Falkner B, Gazdicc MA. Fluid and electrolyte; in Sol S Zimmerman; Philadelphia, WB Saunders: $1985 ; 55-61$. sion making in critical care. BC Decker. Inc; Toronto; 1985; 154-5.

6. Kappy MS. Hyperkalemia; in Behrman s (Ed) Pediatric decision making. Philadelphia: BC Decker Inc; 1985: 82-3.Stephan Behrman ed; BC Decker Inc; Philadelphia; 1985; 82-3.

7. Lindenfeld SM. Hyperkalemia; in Don $H(E d)$ Decision making in critical care. Toronto: $B C$ Decker Inc, 1985; 156-7.

8. Swenson. Fluid and electrolyte in pediatric surgery, Jhon G. Raffensperger ed; Fifth Ed; Appleton \& Lange 1990; 73-9.
5. Hansen R. Hyponatremia; in Don $H$ (Ed) Deci- 